\title{
Complicación tardía de la ureterosigmoideostomía
}

\author{
Jalón Monzón A, Álvarez Múgica M, Sánchez Trilla A, González Álvarez RC, Martín Benito JL, \\ Regadera Sejas FJ.
}

Servicio de Urología 1. Hospital Universitario Central de Asturias. Oviedo. Asturias.

Actas Urol Esp. 2007;31(1):65

$\mathrm{V}$

arón de 66 años remitido desde consultas de nefrología para valorar inclusión en lista de Transplante Renal. Intervenido en la infancia de probable extrofia vesical realizándose ureterosigmoideostomía bilateral. En la actualidad presenta Insuficiencia Renal Crónica avanzada precisando de diálisis tres veces por semana. El TC realizado (Figs. 1 y 2) revela una marcada atrofia cortical con importante hidronefrosis, observándose gas rellenando el sistema pielocalicial y ambos uréteres drenando estos por separado en el colon sigmoide. No se identifica vejiga.

La incidencia de sepsis y de insuficiencia renal es mayor en los pacientes con ureterosigmoideostomía que en aquellos con conductos ileales, pudiendo ocurrir durante el periodo postoperatorio inmediato o muchos años más tarde. La causa más común de muerte en los pacientes portadores de una ureterosigmoideostomía cuya derivación fue realizada más de 15 años antes, es la insuficiencia renal adquirida. Entre el 10-22\% de estos pacientes mueren por estos trastornos, frente al 6\% de aquellos con conducto ileal.

Correspondencia autor: Dr. A. Jalón Monzón.

Servicio de Urología. Hospital Univ. Central de Asturias.

Celestino Villamil, s/n. 33006 Oviedo - Asturias.

Tel.: 985108000

E-mail autor: ajalonm@Hotmail.com

Información artículo: Imágenes en Urología

(Trabajo aceptado diciembre 2005)

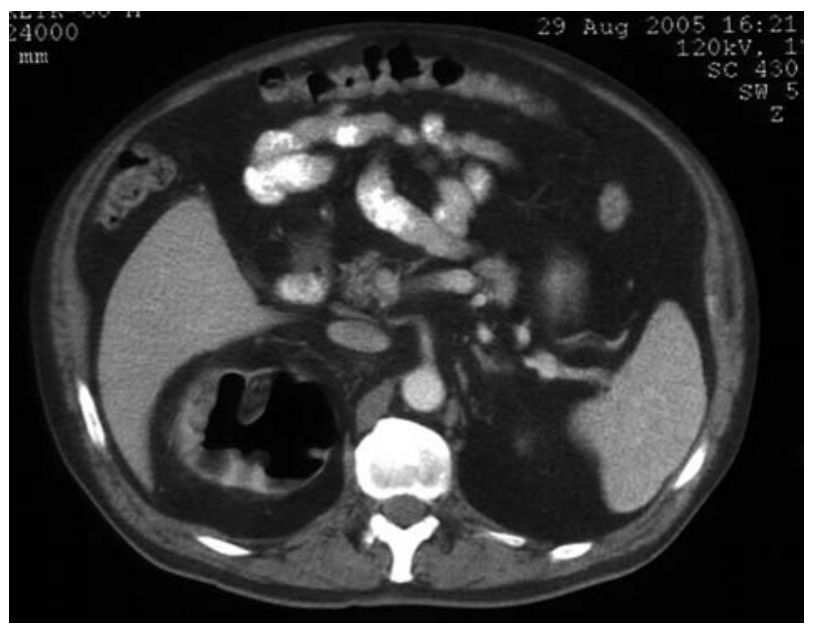

\section{FIGURA 1}

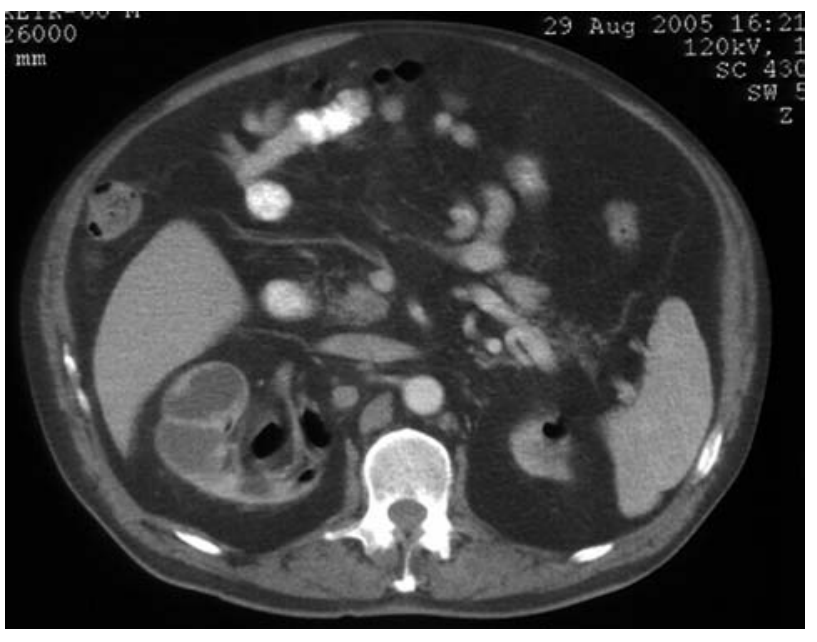

FIGURA 2 